\title{
Perbandingan Model Guided Discovery Learning Dengan Kooperatif Jigsaw Dipadu Eksperimen Terhadap Keterampilan Proses Sains Siswa
}

\section{The Comparison Between Guided Discovery And Cooperative Jigsaw Learning Combined with Experimenting in Term of Students' Science Process Skills}

\author{
AS SYAFFA AL LIINA ${ }^{1}$, MARIDI ${ }^{* 1}$, HARLITA $^{1}$ \\ ${ }^{1}$ Pendidikan Biologi, Fakultas Keguruan dan Ilmu Pendidikan \\ Universitas Sebelas Maret, Jl. Ir. Sutami No. 36 A Kentingan, Surakarta, Indonesia \\ *Corresponding authors: maridi_uns@yahoo.co.id \\ Manuscript received: ......... Revision accepted:
}

\begin{abstract}
This research is quasi experimental research. The research design used posttest only group design. General population is all science students of class X SMA. The research sample are the students of X-MIPA SMA as the first experiment group (the applied of Guided Discovery Learning model) that contains 30 students and X MIPA 2 as the second experiment group (The applied of Jigsaw Cooperative fused by experiment) that contains 30 students. The sampling method that used was the cluster sampling. The collecting data method used essay test for measuring student's science process skill, observation list for evaluate syntax model activity, and school documents. Validity test that used was coefficient formula Product moment by Karl Pearson and reliability test that used was Alfa Cronbach formula. Prerequisite test analysis consisted of normality test and homogeneity test. Normality was analyzed by Kolmogorov-Smirnov test and homogeneity was analyzed by Levene'e test. The result was showed that all groups were in normal distribution and homogeneous data. The analysis data used $t$ test with significance level 0,05 . Hypothesis test by using $t$ test showed that signification value was $0,000<$ 0,05 so $\mathrm{H} 0$ is rejected, it means that there is a significant difference of Science Process Skills ability between the first experiment class and the second experiment class. The post test average score of the first experiment is 57,17 and the second experiment is 68,8 . Based on that result, it is concluded that Jigsaw Cooperative Model fused by experiment give more significant influence toward student's science process skill compared to Guide Discovery Learning Model.
\end{abstract}

Keywords: Guided Discovery Learning, Jigsaw, Science Process Skills.

\section{PENDAHULUAN}

Keterampilan proses sains (KPS) merupakan keterampilan yang melibatkan segenap kemampuan siswa dalam memperoleh pengetahuan berdasarkan fenomena. Kemampuan siswa yang dimaksud adalah keterampilan mengamati, mengelompokkan, menafsirkan, memprediksi, mengajukan pertanyaan, berhipotesis, merencanakan percobaan, menggunakan alat dan bahan, menerapkan konsep, berkomunikasi dan melaksanakan percobaan (Rustaman, 2005). Keterampilan proses sains penting dalam pembelajaran saat ini karena, perkembangan ilmu pengetahuan dan teknologi berlangsung semakin cepat sehingga tidak mungkin lagi guru mengajarkan semua konsep dan fakta pada siswa, adanya kecenderungan bahwa siswa lebih memahami konsep-konsep yang rumit dan abstrak jika disertai dengan contoh yang konkret, penemuan dan perkembangan ilmu pengetahuan dan teknologi tidak bersifat mutlak, tapi bersifat relatif, dalam proses belajar mengajar, pengembangan konsep tidak terlepas dari pengembangan sikap dan nilai dalam diri anak didik (Semiawan, 1992).
Keterampilan proses sains erat kaitannya dengan pembelajaran sains. Pembelajaran sains bertujuan agar siswa dapat menguasai konsep-konsep IPA. Pembelajaran sains yang baik harus menjadikan siswa tidak sekedar tahu dan hafal tentang konsep-konsep sains, tetapi juga harus menjadikan siswa terampil berpikir,bersikap, dan bertindak berdasarkan pemahaman tentang konsep dan prinsipprinsip sains. Pembelajaran sains salah satunya adalah pembelajaran biologi. Biologi sebagai bagian sains terdiri dari dua aspek yang saling terkait, yaitu biologi sebagai produk diartikan sebagai struktur tubuh pengetahuan yang terdiri dari fakta, konsep, hukum, teori, dan generalisasi. Biologi sebagai proses diartikan sebagai proses berpikir untuk menemukan produk biologi. Berdasarkan penjabaran tersebut, maka dapat diartikan bahwa biologi bukan hanya sekedar fakta-fakta atau teori yang harus dihafal, tetapi juga suatu kegiatan atau proses aktif menggunakan pikiran untuk membangun fakta dan manual tersebut.

United Nations Educational, Scientific and Cultural Organization (UNESCO) melalui International Commission on Education for The Twenty First Century telah merekomendasikan empat pilar pendidikan, yaitu 
learning to do, learning to know, learning to be, and learning to live together (Kemendiknas, 2001). Pembelajaran sains tidak seharusnya hanya menempatkan siswa sebagai pendengar ceramah dari guru. Siswa harus diberdayakan agar mau dan mampu berbuat untuk memperkaya pengalaman belajar (learning to do) dengan meningkatkan interaksi dengan lingkungan fisik dan sosial, sehingga mampu membangun pemahaman dan pengetahuan terhadap dunia di sekitar (learning to know). Hasil interaksi siswa dengan lingkungan diharapkan dapat membangun pengetahuan dan kepercayaan diri dan sekaligus membangun jati diri siswa (learning to be). Kesempatan siswa berinteraksi dengan berbagai individu atau kelompok individu yang bervariasi akan membentuk kepribadian untuk memahami kemajemukan dan melahirkan sikap-sikap positif dan toleran terhadap keanekaragaman dan perbedaan hidup (learning to live together).

Rendahnya keterampilan proses sains di sekolah dapat dilihat dari hasil penelitian Astuti (2012) menunjukkan bahwa kompetensi siswa Indonesia usia 15 tahun (SMP) sebanyak 61,6\% memiliki pengetahuan sains sangat terbatas atau berada di bawah level 1. Sementara siswa SMP diharapkan minimal di level 2, yaitu dapat melakukan penelitian sederhana. Sebanyak 27,5\% berada di level 2. Pada level 3 hanya 9,5\% siswa yang mampu mengidentifikasi masalah-masalah ilmiah. Di level 4 hanya $1,4 \%$ siswa yang mampu memanfaatkan sains untuk kehidupan. Sedangkan pada level 6 (tertinggi), belum ada siswa Indonesia yang berhasil mencapainya, yakni secara konsisten mampu mengidentifikasi, menjelaskan, serta mengaplikasikan pengetahuan sains dalam berbagai situasi kehidupan yang kompleks.

Pembelajaran yang berpotensi mampu mengatasi permasalahan siswa terhadap kurang terbedayakannya keterampilan proses sains yang sesuai dengan Kurikulum 2013 adalah pembelajaran berbasis kontruktivis. Model pembelajaran konstruktivis melatihkan siswa terlibat aktif serta mengakomodasi keterampilan proses sains dalam pembelajaran dan guru hanya sebagai fasilitator, sehingga siswa dapat membangun konsep sendiri. Karakteristik pembelajaran biologi berkaitan dengan cara mencari tahu dan memahami alam, dalam pembelajaran biologi siswa tidak hanya diharapkan mampu menguasai fakta, konsep maupun prinsip saja melainkan proses penemuan pengetahuan, sehingga dalam mengembangkan pembelajaran biologi diharapakan keterlibatan aktif siswa dalam pembelajaran untuk menemukan sendiri pengetahuan melalui interaksi dalam lingkungan.

Kedudukan model pembelajaran dalam kegiatan belajar mengajar sangat penting. Model pembelajaran yang bervariasi membuat siswa akan tertarik dalam mengikuti pembelajaran, serta memudahkan guru dalam menyampaikan materi lebih mudah dipahami dan tujuan pembelajaran dapat tercapai secara optimal. Beberapa model, strategi, dan pendekatan yang berpotensi untuk mengembangkan keterampilan proses sains antara lain adalah model Guided Discovery Learning, Active Learning, dan Cooperatif Learning (Purwanto, 2012). Model Guided Discovery Learning merupakan salah satu model pembelajaran inovatif yang memberdayakan proses berpikir melalui penemuan.
Keterampilan Proses Sains dapat ditingkatkan dengan menerapkan Model Guided Discovery Learning karena memiliki sintak Hypothesis generation dan hypothesis testing. Pada sintak Hypothesis generation siswa diminta menemukan hipotesis berdasarkan pendapat sementara siswa, hal ini dapat mengembangkan aspek observasi atau mengamati siswa kareana siswa dituntut untuk menemukan pengetahuannya sendiri berdasarkan pengetahuan yang telah dimiliki siswa. Sedangkan pada sintak hypothesis testing siswa diminta untuk melakukan percobaan atau eksperimen. Pada kegiatan eksperimen siswa terlibat langsung mulai dari mengamati hasil eksperimen, mengklasifikasikan macam-macam pencemaran, membuat hipotesis eksperimen, menggunakan alat dan bahan saat eksperimen, melakukan eksperimen, mengkomunikasikan, dan menyimpulkan hasil eksperimen. Pada kegiatan eksperimen tersebut siswa dilatih untuk mengunakan keterampilan proses sains.

Menurut Nwagbo dalam Akinbobola dan Afolabi (2010), model Guided Discovery Learning merupakan pembelajaran kontruktivis, guru memberikan ilustrasi permasalahan, kemudian memberikan pertanyaan untuk memberdayakan kemampuan berpikir siswa dalam menyusun kesimpulan sebagai pemecahan masalah. Sedangkan menurut Asmani (2010), model Guided Discovery Learning merupakan model untuk mengembangkan cara belajar siswa aktif dengan menemukan sendiri, menyelidiki sendiri, maka siswa memperoleh pengetahuan melalui pengalaman yang dilakukan serta dapat meningkatkan proses berpikir siswa. Menurut Suryosubroto (2002), seorang guru dalam menerapkan model Guided Discovery Learning, diantaranya guru mengemukakan masalah, memberi pengarahan mengenai pemecahan, dan membimbing siswa dalam hal mencatat data. Model Guided Discovery Learning melatihkan untuk mengajarkan konsep dan hubungan antar konsep. Menurut David (2009), dalam menerapkan model Guided Discovery Learning, guru sedikit menjelaskan tetapi lebih banyak untuk mengajukan pertanyaan sehingga siswa cenderung aktif dan memotivasi siswa dalam kegiatan pembelajaran.

Model pembelajaran lain yang mampu mengakomodasi keterampilan proses sains, yaitu kooperatif jigsaw karena dapat mendorong siswa untuk mengembangkan keterampilan proses sains terutama pada materi pencemaran lingkungan. Hal tersebut karena materi pencemaran lingkungan memilki kegiatan-kegiatan seperti mengamati hasil eksperimen, mengklasifikasikan macammacam pencemaran, membuat hipotesis eksperimen pengaruh detergen terhadap kelangsungan hidup ikan, merencanakan eksperimen, menggunakan alat dan bahan saat eksperimen, melakukan eksperimen, mengkomunikasikan, dan menyimpulkan. Model kooperatif Jigsaw memfasilitasi siswa secara individual untuk mengembangkan kemampuan dalam berbagai aspek. Kegiatan diskusi pada model Jigsaw ini dapat memunculkan proses scaffolding melalui tutorial sebaya, yakni teman mengajarkan materi pembelajaran kepada teman yang lain. Proses scaffolding perlu digunakan sebagai upaya peningkatan keterampilan sains siswa terutama pada aspek mengkomunikasikan data yang 
diperoleh, hal ini merupakan keunggulan koopratif jigsaw dibandingkan model Guided Discovery Learning.

Meskipun demikian pada karakteristik pembelajaran tertentu, misalnya dalam pembelajaran sains, penerapan Kooperatif Jigsaw menjadi kurang optimal. Pada pembelajaran sains, khususnya biologi pemahaman materi saja tidak cukup. Pemahaman materi dan penguasaan konsep dapat dioptimalkan jika siswa diberikan kesempatan untuk berproses secara ilmiah mencari dasardasar darimana konsep tersebut didapat. Proses pencarian konsep secara ilmiah itu dapat melalui pembelajaran yang menerapkan pengalaman langsung pada objek pembelajaran, seperti pembelajaran dengan model praktikum atau eksperimen. Maka diperlukan perpaduan model kooperatif jigsaw dengan eksperimen untuk mengasah keterampilan proses sains siswa.

Kegiatan eksperimen atau praktikum di dalam pendidikan IPA merupakan bagian integral dari kegiatan belajar mengajar, khususnya biologi. Hal ini menunjukkan pentingnya peranan kegiatan eksperimen laboratorium untuk mencapai tujuan pendidikan IPA. Melalui kegiatan eksperimen, siswa akan mendapatkan pengalaman secara langsung. Menurut Rustaman, dkk. (2005), pengalaman langsung akan dapat mengembangkan keterampilanketerampilan dasar IPA. Keterampilan-keterampilan dasar IPA antara lain mengamati objek penelitian, menggunakan angka, mengelompokkan data hasil-hasil pengamatan, mengukur objek, mengkomunikasikan hasil pengamatan, menyimpulkan hasil pengamatan. Hal ini diperkuat oleh Myers (2006) yang menyatakan bahwa eksperimen adalah aspek yang paling menarik dari kelas sains dan siswa tidak dapat melakukan eksperimen tanpa keterampilan proses sains. Keterampilan proses sains dalam eksperimen di antaranya keterampilan merencanakan percobaan, menggunakan alat dan bahan, dan menjelaskan hasil percobaan.

Pelaksanakan kegiatan eksperimen dalam pembelajaran sains sering dihadapkan pada beberapa kendala, di antaranya terlalu banyak jumlah siswa di kelas. Solusi untuk mengatasi masalah tersebut biasanya guru melaksanakan kegiatan eksperimen ini secara berkelompok, namun terdapat kekurangan dari kerja kelompok konvensional, yaitu anggota kelompok yang malas akan menyerahkan segalanya kepada teman yang lebih pandai atau rajin dan seluruh waktu belajar didominasi oleh siswa yang pandai dan siswa yang berani berbicara. Oleh karena itu, diperlukan model pembelajaran alternatif khususnya dalam kegiatan eksperimen yang dapat mengatasi masalah tersebut. Menurut Slavin (2009), apabila dalam pengelompokkan siswa diatur secara baik, maka siswa- siswa dalam kelompok ini akan belajar satu sama lain untuk memastikan bahwa setiap anggota kelompok telah menguasai konsep-konsep yang telah dipikirkan. Model pembelajaran yang dapat menjadikan siswa berperan sebagai tutor bagi teman sebayanya salah satunya adalah model pembelajaran kooperatif jigsaw. Perpaduan antara pembelajaran kooperatif Jigsaw dengan eksperimen merupakan salah satu wujud modifikasi dan inovasi dalam pembelajaran. Memadukan kedua model tersebut, selain siswa mampu meningkatkan pembelajaran melalui proses scaffolding, siswa juga akan dapat mengembangkan berbagai kompetensi dan keterampilan siswa, di antaranya adalah keterampilan proses sains (KPS)..

\section{METODE PENELITIAN}

Penelitian eksperimen semu ini menggunakan rancangan penelitian post test only group design. Tes hanya diberikan pada akhir pembelajaran (post-test) untuk menilai keterampilan proses sains siswa. Sedangkan untuk menguji homogenitas awal keterampilan proses sains siswa menggunakan nilai psikomotorik PAS semester ganjil dimana nilai psikomotik tersebut telah mencangkup aspekaspek dari keterampilan proses sains siswa. Dalam penelitian ini digunakan dua kelompok kelas yang memiliki karakter sama atau hampir sama. Kelompok pertama disebut kelas eksperimen 1 diterapkan model pembelajaran model guided discovery learning, sedangkan pada kelas eksperimen 2 diterapkan model pembelajaran kooperatif jigsaw dipadu eksperimen.

Tabel 1. Desain Penelitian

\begin{tabular}{ccc}
\hline Kelompok & Treatment & Post test \\
\hline Eksperimen 1 & $\mathrm{X} 1$ & $\mathrm{O} 1$ \\
\hline Eksperimen 2 & $\mathrm{X} 2$ & $\mathrm{O} 2$ \\
\hline
\end{tabular}

Keterangan:

$\mathrm{X}_{1}$ : Pembelajaran model guided discovery learning

$\mathrm{X}_{2}$ : Perlakuan model koopertatif jigsaw dipadu eksperimen

$\mathrm{O}_{1}$ : Tes akhir yang diberikan kepada kelompok eksperimen 1

$\mathrm{O}_{2}$ : Tes akhir yang diberikan kepada kelompok eksperimen 2

Teknik pengambilan sampel yang digunakan pada penelitian ini adalah Cluster Sampling berdasarkan uji homogenitas dan normalitas didapatkan sampel penelitian dari 2 kelas, yaitu kelas X-MIPA 1 dan X-MIPA 2. Nilai yang digunakan untuk uji homogenitas dan normalitas kelas adalah Penilaian Akhir Semester (PAS).

Teknik pengumpulan data menggunakan tes uraian, dokumentasi, dan observasi. Uji prasyarat hipotesis menggunakan uji normalitas dan homogenitas. Uji hipotesis menggunakan uji t dengan taraf signifikansi $5 \%$. Analisis data dibantu dengan SPSS 2016.

\section{HASIL DAN PEMBAHASAN}

KPS siswa diukur dari tes uraian pada materi pencemaran lingkungan. Data KPS diambil dari dua kelas, yaitu kelas X-MIPA1 sejumlah 30 siswa sebagai kelas eksperimen 1 dengan model guided discovery learning dan kelas XMIPA2 berjumlah 30 siswa sebagai kelas eksperimen 2 dengan model kooperatif jigsaw dipadu eksperimen. Distribusi nilai KPS dapat dilihat pada Tabel 1.

Tabel 2. Distribusi Nilai KPS Kelas Eksperimen 1 dan Kelas Eksperimen 2 


\begin{tabular}{cccccc}
\hline \multicolumn{3}{c}{ Kelas Eksperimen 1 } & \multicolumn{3}{c}{ Kelas Eksperimen 2 } \\
\hline No & Nilai & Siswa & No & Nilai & Siswa \\
\hline 1 & $31-40$ & 0 & 1 & $31-40$ & 1 \\
2 & $41-50$ & 7 & 2 & $41-50$ & 1 \\
3 & $51-60$ & 10 & 3 & $51-60$ & 3 \\
4 & $61-70$ & 12 & 4 & $61-70$ & 11 \\
5 & $71-80$ & 1 & 5 & $71-80$ & 8 \\
6 & $81-90$ & 0 & 6 & $81-90$ & 6 \\
\multicolumn{2}{c}{ Jumlah } & 30 & Jumlah & 30 \\
\hline
\end{tabular}

Berdasarkan Tabel 2 memperlihatkan distribusi nilai KPS pada kelas eksperimen 1 yang menggunakan model guided discovery learning memiliki frekuensi sebanyak 0 siswa yang mendapatkan nilai 31-40, sebanyak 7 siswa yang mendapatkan nilai 41-50, sebanyak 10 siswa yang mendapatkan nilai 51-60, sebanyak 12 siswa yang mendapatkan nilai 61-70, sebanyak 1 siswa yang mendapatkan nilai 71-80. Sedangkan pada kelas eksperimen 2 yang menggunakan model kooperatif jigsaw

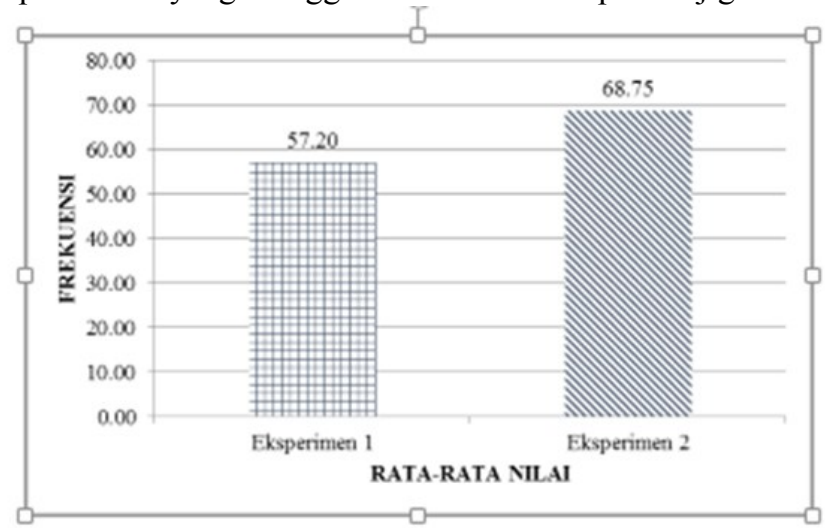

dipadu eksperimen memiliki frekuensi sebanyak 1 siswa yang mendapatkan nilai 31-40, sebanyak 1 siswa yang mendapatkan nilai 41-50, sebanyak 3 siswa yang mendapatkan nilai 51-60, sebanyak 11 siswa yang mendapatkan nilai 61-70, sebanyak 8 siswa yang mendapatkan nilai 71-80, sebanyak 6 siswa yang mendapatkan nilai 81-90. Pada kelas eksperimen 2 frekuensi siswa yang mendapat rentang nilai tinggi lebih banyak dibandingkan pada kelas ekspeimen 1. Perbandingan rata-rata nilai posttest kedua kelas dapat dilihat pada Gambar 1.

Gambar 1. Rata-rata Nilai KPS pada Kelas Eksperimen 1 dan Kelas Eksperimen 2

Gambar 1 menunjukkan bahwa rata-rata nilai KPS pada kedua kelas berbeda. Skor rata-rata nilai KPS pada kelas eksperimen 2 lebih besar daripada kelas eksperimen 1.Hasil penelitian menunjukkan bahwa model kooperatif jigsaw dipadu eksperimen lebih berpengaruh signifikan terhadap KPS dibandingkan dengan model Guided Discovery Learning. Hal ini dikarenakan tidak semua siswa dapat mengikuti pelajaran dengan model Guided Discovery Learning. Siswa masih takut untuk mengeluarkan pendapat atau bertanya jika ada suatu hal yang belum dimengerti. Beberapa siswa tidak banyak terlibat dalam diskusi dan tanya jawab kelompok, sehingga jarang sekali mengajukan pertanyaan. Kurangnya keterlibatan siswa dalam setiap sintaks model guided discovery learning membuat siswa kurang maksimal dalam melatih KPS. Sementara itu hasil belajar siswa dengan menggunakan model kooperatif jigsaw dipadu eksperimen lebih berpengaruh terhadap KPS siswa. Hal ini dikarenakan model kooperatif jigsaw dipadu eksperimen mendukung untuk memunculkan indikatorindikator dalam KPS. KPS melibatkan keterampilanketerampilan kognitif, keterampilan manual dan keterampilan sosial (Rustaman, dkk., 2005). Model kooperatif jigsaw dipadu eksperimen dapat mengakomodasi semua keterampilan tersebut. Pembelajaran kooperatif dapat melatih social skill karena siswa belajar dalam bentuk grup. Khususnya pembelajaran sains, pembelajaran kooperatif ini dinilai sangat efektif karena siswa selalu bekerja dalam kelompok ketika melakukan eksperimen. Kegiatan kelompok pada pembelajaran kooperatif lebih menekankan non-kognitif proses pembelajaran seperti komunikasi dan keterampilan sosial (Jansoon, 2008).

Pembelajaran kooperatif jigsaw mengenal adanya proses scaffolding dimana siswa berkemampuan akademik atas memberikan tutorial terhadap siswa berkemampuan akademik bawah (Slavin 2009). Fase pembelajaran kooperatif jigsaw siswa bertanggung jawab untuk mengajarkan materi pada teman satu grupnya, disinilah terjadi proses tutorial sebaya (scaffolding). Proses scaffolding ini akan meningkatkan pemahaman siswa, sehingga dapat meningkatkan keterampilan kognitif siswa. Scaffolding dirancang untuk mendukung pengembangan konsep siswa (Warwick \& Mercer, 2011). Hal ini sesuai dengan teori konstruktivisme dari Vygotsky yang menyatakan bahwa interaksi individu dengan orang lain merupakan faktor terpenting yang dapat memicu perkembangan kognitif seseorang.

Metode eksperimen menekankan pada pengalaman langsung dimana siswa harus meneliti sendiri, mengamati, menganalisis, memahami prosedur kerja, dan menarik kesimpulan sendiri. Kegiatan-kegiatan tersebut akan melatih keterampilan kognitif dan keterampilan manual siswa. Metode eksperimen erat kaitannya dengan KPS karena dalam setiap tahapan metode eksperimen akan mengakomodasi keterampilan dasar (basic skill) dan keterampilan terintegrasi (integrated skill) pada siswa. Terdapat hubungan yang signifikan dan positif antara basic skill dan integrated skill yang terjadi pada aplikasi pembelajaran di laboratorium (Feyzioğlu, 2009). KPS siswa yang muncul dalam metode eksperimen dapat diperkuat dengan adanya proses scaffolding yang terdapat 
dalam model jigsaw. KPS akan berkembang melalui metode eksperimen dan pemahaman siswa akan meningkat melalui model jigsaw. Hal tersebut relevan dengan teori belajar Piaget yaitu peserta didik mengkontruksi pengalaman-pengalaman baru yang diperoleh yang secara tidak langsung memaksa peserta didik untuk mendasarkan diri dan memodifikasi pengetahuan pada pengetahuan sebelumnya (Trianto, 2007).

Dalam penelitian ini, kegiatan praktikum yang dilakukan oleh siswa mengembangkan keterampilan mengobservasi, mengklasifikasikan, menggunakan alat/bahan, berkomunikasi, menyimpulkan, mengajukan pertanyaan, dan berhipotesis. Keterampilan mengobservasi siswa diperoleh dari kegiatan siswa mengamati keadaan ikan yang dimasukkan dalam air deterjen, cacing yang dimasukkan dalam tanah yang telah dicampur pupuk, dan mengamati perubahan warna pada kertas indikator universal $\mathrm{pH}$ untuk mengukur $\mathrm{pH}$ air. Keterampilan mengklasifikasikan dari siswa mengelompokkan air tercemar dan air bersih. Keterampilan menggunakan alat dan bahan dari cara kerja tiap praktikum yang menggunakan alat dan bahan yang berbeda. Keterampilan berkomunikasi dari menuliskan hasil pengamatan ke dalam tabel pengamatan serta mengonversikannya ke dalam grafik. Keterampilan menyimpulkan dari kegiatan mereka menyimpulkan hasil pengamatan praktikum. Keterampilan mengajukan pertanyaan dari kegiatan tanya jawab, dan keterampilan berhipotesis diperoleh dari cara siswa merumuskan dugaan awal sebelum memulai praktikum. Pelaksanaan eksperimen berjalan lancar karena siswa telah memahami prosedur eksperimen yang dilakukan. Siswa juga terlihat aktif saat melakukan eksperimen karena tidak hanya belajar teori pencemaran lingkungan saja tetapi langsung bisa mempraktekkan sendiri dampak pencemaran air di lingkungan dengan alat dan bahan yang cukup sederhana. Hal ini sesuai dengan teori Ausubel yang menyatakan bahwa belajar bermakna akan terjadi saat peserta didik ikut terlibat aktif selama proses pembelajaran berlangsung (Dahar, 2006).

Sintaks model kooperatif jigsaw sebagai badan utama pembelajaran, sedangkan unsur eksperimen dimasukkan ke dalam fase diskusi tim ahli (expert team) dalam tahapan dari sintaks kooperatif jigsaw ini. Fase diskusi tim ahli (expert team) memegang peranan penting dalam pembelajaran ini. Pada fase ini siswa dalam kelompok ahli melakukan kegiatan praktikum. Kegiatan praktikum terbagi menjadi 4 sub topik pencemaran lingkungan yang berbeda-beda. Setiap kelompok ahli melakukan praktikum dengan judul yang berbeda-beda pula. KPS siswa berkembang cukup nyata dalam fase ini. Pada tahap laporan kelompok ahli (expert team) kepada kelompok asal (home team), setiap anggota kelompok asal berdiskusi untuk membahas hasil praktikum yang telah dilaksanakan masing-masing anggota. Pada fase ini terjadi proses scaffolding, anggota pada kelompok ahli akan mengajarkan materi yang diperoleh dari kelompok ahli (expert team) kepada seluruh anggota tim asal (home team).

Pembelajaran ini juga mengacu pada pendekatan heuristik yang memandang scientist sebagai penemu (discoverer) (Rustaman, dkk., 2005). Pada kegiatan praktikum yang dilaksanakan, siswa bagaikan seorang scientist yang sedang melakukan eksperimen, mulai dari merumuskan masalah, melakukan eksperimen, menggunakan alat bahan, melakukan pengukuran, menginterpretasikan data yang diperoleh, serta mengkomunikasikan data tersebut.

Pembelajaran kooperatif jigsaw ini juga dapat membuat siswa menjadi lebih aktif dalam berbicara dan berpendapat. Hasil pengamatan menunjukkan masingmasing siswa sudah dapat berperan aktif dalam kegiatan kelompoknya. Siswa dalam kelas eksperimen 2 lebih berani untuk berpendapat dan mengajukan pertanyaan. Fenomena tersebut tidak terjadi di kelas eksperimen 1 dimana ketika guru meminta siswa dalam kelompok menerangkan dampak pencemaran air, siswa saling menunjuk temannya tidak berinisiatif menjawab sendiri. Hal ini disebabkan guru tidak mengarahkan pembagian kerja dalam kelompok. Menurut Hanze dan Berger (2007), keuntungan dari kelas jigsaw adalah siswa lebih terlibat dan lebih tertarik pada materi dalam pembelajaran kooperatif daripada dalam pembelajaran konvensional yang berupa instruksi. Killic (2008) juga menyatakan bahwa dalam penyelenggaraan model kooperatif jigsaw lebih menyenangkan dibandingkan dengan pembelajaran konvensional dan ia juga menambahkan bahwa model ini seharusnya digunakan di semua fase pendidikan.

Serangkaian kegiatan dalam pembelajaran kooperatif jigsaw melalui eksperimen ini menggambarkan bahwa pembelajaran ini tidak hanya efektif dalam meningkatkan KPS siswa, tetapi juga efektif dalam meningkatkan pemahaman siswa. Pemahaman siswa akan bersifat long term memory (mengendap di ingatan dalam waktu yang lama). Rustaman, dkk. (2005), menyatakan bahwa dengan melakukan suatu eksperimen siswa akan lebih yakin pada suatu hal, memperkaya pengalaman, mengembangkan sikap ilmiah, dan hasil belajar akan lebih lama dalam ingatan siswa. Potensi dari pembelajaran kooperatif jigsaw adalah dapat mempermudah siswa dalam penguasaan konsep, sehingga siswa dapat memperoleh prestasi yang maksimal. Hal ini releven dengan penelitian mengenai pengaruh penerapan metode praktikum terhadap KPS yang dilakukan oleh Dewi (2010) menerapkan metode praktikum pada siswa kelas XI IPA SMA Pasundan 2 Bandung semester ganjil tahun ajaran 2010/2011, hasilnya adalah terdapat peningkatan presentase antara pre test dan post test KPS setelah setelah kelas diterapkan metode praktikum. Presentase peningkatan keterampilan proses yang paling tinggi mencapai $42,41 \%$ dan presentase peningkatan keterampilan proses yang paling rendah adalah 4,05\%. Penelitian serupa dilakukan oleh Kurnia (2010) yang menganalisis KPS dengan menggunakan metode praktikum terhadap salah satu sekolah negeri di kota bandung, hasilnya adalah KPS mengalami peningkatan sebesar 92,86\% untuk keterampilan mengamati dan $88,70 \%$ untuk keterampilan merencanakan percobaan.

Berdasarkan hasil penelitian tersebut, terbukti bahwa perkembangan KPS sangat dipengaruhi oleh kegiatan praktikum. Model kooperatif jigsaw juga memberi kontribusi dalam pembelajaran sains. Dalam pendidikan sains, model jigsaw dan variannya dapat digunakan di kelas lebih sering daripada model lain, terutama dalam biologi, hal ini karena model jigsaw dianggap dapat meningkatkan pembelajaran kooperatif dengan membuat setiap siswa 
fokus pada topik tertentu dan membuat siswa dapat memperdalam kognitif dan afektifnya (Jansoon, 2008).

\section{SIMPULAN}

Berdasarkan hasil penelitian tentang perbandingan model guided discovery learning dengan kooperatif jigsaw dipadu eksperimen terhadap KPS siswa kelas X SMA, maka dapat disimpulkan berikut :

1. Ada perbedaan signifikan rata-rata keterampilan proses sains siswa pada materi perubahan lingkungan antara kelas eksperimen 1 menggunakan model guided discovery learning dengan kelas eksperimen 2 menggunakan model kooperatif jigsaw dipadu eksperimen.

2. Hasil rata-rata nilai post test kelas eksperiemen 1 sebesar 57,17 dan kelas eksperiemen 2 sebesar 68,8.

3. Kelas eksperimen 2 (model kooperatif jigsaw dipadu eksperimen) lebih berpengaruh terhadap KPS dibandingkan kelas eksperimen 1 (model guided discovery learning).

\section{DAFTAR PUSTAKA}

Abraham, I. M. (2008). Study of the effectiveness of practical work as a teaching and learning method in school science. International journal of science education. 30, (14), 1945-1969.

Akinbobola, A. A. (2010). Analysis of science process skills in west african senior secondary school certificate physics practical examinations in nigeria. Ameerican-eurasia journal of scientific research 5 (4), 234-240.

Ali, M. (2004). Penelitian Kependidikan Prosedur Strategi. Bandung: Angkasa.

Arikunto, S. (2010). Dasar-dasar evaluasi pendidikan (edisi revisi). Jakarta: Bumi Aksara.

Asmani, M. (2010). Panduan efektif bimbingan dan konseling di sekolah. Jogjakarta: Diva Press.

Astuti, R. (2012). Pembelajaran IPA dengan pendekatan keterampilan proses sains menggunakan metode eksperimen bebas termodifikasi dan eksperimen terbimbing ditinjau dari sikap ilmiah dan motivasi belajar siswa. Jurnal inkuiri, 51-59.

Bundu, P. (2006). Penilaian keterampilan proses dan sikap ilmiah dalam pembelajaran sains-SD. Jakarta: DEPDIKNAS.

Dahar. (2006). Teori- teori belajar. Jakarta: Erlangga.

Darmadi, H. (2011). Metode penelitian pendidikan. Bandung: Alfabeta.

David, A. P. (2009). Methods for teaching. Jogjakarta: Putaka Pelajar.

Dillon, J. (2008). A review of the research on practica work in school science. london: King's College.

Dwiyanti, G. S. (2005). Keterampilan proses sains siswa SMU kelas ii pada pembelajaran kesetimbangan kimia melalui metode praktikum. Laporan penelitian FPMIPA UPI Bandung.

Gillies, R. (2006). Teachers and students verbal behavior during cooperative and small group learning. British journal education psychology.
Hamalik. (2006). Proses belajar mengajar. Bandung: Bumi Aksara.

Ilmi, A. I. (2012). Pengaruh penerapan model pembelajaran guided discovery terhadap keterampilan proses sains siswa kelas X SMA Negeri 1 Teras Boyolali. Jurnal pendidikan biologi 4 (2), 44-52.

Indarti. (2010). Penerapan model pembelajaran cooperatif learning tipe jigsaw melalui praktikum terhadap hasil belajar siswa pada konsep klasifikasi makhluk hidup. Skripsi Tidak Dipublikasikan, Universitas Pendidikan Indonesia, Bandung

Isjoni. (2007). Cooperatif learning mengembangkan kemampuan belajar berkelompok. Bandung: Alfabeta.

Jiwanto, I. N. (2017). Pengaruh implementasi model pembelajaran inkuiri terbimbing kooperatif jigsaw terhadap keterampilan proses sains siswa SMP. Jurnal pendidikan IPA Veteran, 1-8.

Karamustafaoğlu, S. (2011). Improving the science process skills ability of science student teachers using $\mathrm{i}$ diagram. Eurasian journalpysicchemistry education. 3 (1), 26-38.

Ketpichainarong, W. P. (2010). Enchanted learning of biotechnology students by an inquiry-based cellulase laboratory. international journal of enviroment \& science. Vol 5, No. 2, April 2010, 169-187.

Killic, D. (2008). The effect of jigsaw teechnique on learning the concepts of the principles and methods of teaching. World applied science journal. Vol 4 (Supple 1), 109-114.

Lie, A. (2007). Cooperatif learning : Mempraktikan cooperatif learning di ruang-ruang kelas. Jakarta: Grasindo.

Maksem, L. S. (2016). Peningkatan keterampilan proses sains siswa melalui pembelajaran discovery topik tekanan hidrostatis. Pros. semnas pend. IPA pascasarjana UM. Vol 1.

Markaban. (2006). Model pembelajaran dengan pendekatan penemuan terbimbing. Yogyakarta: Depdiknas.

Mengduo, Q. \&. (2010). Jigsaw strategy as a cooperative learning technique: focusing on the language learners. Chinese journalof applied linguistic (bimonthly), Vol. 33 No. 4 August 2010.

Mudjiono, D. \&. (2006). Belajar \& pembelajaran. Jakarta: Rineka Cipta.

Myers, E. (2006). personal study of science process skils in a general physics classroom. Minnesota: Hamline University.

Nurul, H. (2017). Pengembangan lembar kegiatan siswa (lks) guided discovery pada materi fungi untuk meningkatkan keterampilan proses sains siswa kelas X MIA SMA N 1 Prambanan. Lumbung Pustaka Univeritas Negeri Yogyakarta.

Polacek, K. M. (2005). Easy ways to promote inquiry in a laboratory course. Journal of college science teaching. Vol. 35 No. 1, September 2005.

Purwanto, C. E. (2012). Penerapan model pembelajaran guided discovery pada materi pemantulan cahaya untuk meningkatkan berpikir kritis. Unnes Physics education journal, 26-32.

Rachayuni, R. (2016). Meningkatkan keterampilan proses sains dan hasil belajar IPA melalui penerapan model 
guided discovery di kelas VII-I SMPN 32 semarang. Scientific journal of universitas negeri semarang.Vol 1 No 1.

Rahayu, H. (2017). Analisis profil keterampilan proses sains siswa sekolah dasar di kabupaten sumedang. Jurnal pesona dasar, 22-33.

Rahmawati, T. S. (2017). Penerapan metode guided discovery untuk meningkatkan keterampilan proses sains siswa kelas V netral D. Jurnal pendidikan guru sekolah dasar edisi 5 tahun ke-6.

Rinduwan. (2004). Metode dan teknik menyusun tesis. Bandung: Alfabeta.

Roestiyah. (2001). Strategi belajar mengajar. Jakarta: Rineka Cipta.

Rusman. (2011). Model-model pembelajaran mengembangkan profesionalisme guru. Jakarta: Raja Grafindo.

Rustaman, N. Y. (2005). Strategi belajar megajar biologi. Malang: UM Press.

Sekarwinahyu, M. (2001). Hakikat pembelajaran mipa dan kiat pembelajaran kimia. Jakarta: PAU-PPAI-UT.

Semiawan, C. d. (1992). Pendekatan keterampilan proses. Jakarta: Rineka Cipta.

Setyosari, P. (2010). Metode penelitian pendidikan dan pengembangannya. Jakarta: Kencana Media Group

Slavin, R. E. (2009). Cooperatif learning (teori, riset dan praktik). Bandung: Nusa Media.

Sudjana, N. (2011). Penilaian hasil belajar mengajar. Bandung: PT. Remaja Rosda Karya.

Sugiyono. (2011). Model penelitian pendidikan pendekatan kuantitatif, kualitatif, dan $R \& D$. Bandung: Alfabeta.

Suprijono, A. (2009). Cooperatif learning: Teori dan aplikasi PAIKEM. Yogyakarta: Pustaka Belajar.
Suryosubroto, B. (2002). Proses belajar mengajar. Jakarta: Rineka Cipta.

Susanti, E. (2016). Pengaruh pembelajaran discovery learning terhadap keterampilan sains dan hasil belajar siswa kelas VIII tentang IPA SMP advent palu. Jurnal sains dan teknologi tadulako, Volume 5 Nomer 3, 3641.

Teo, G. d. (2007). Promoting science process skills and the relevance of science through science alive! program. Singapore.

Trianto. (2007). Model pembelajaran terpadu dalam teori dan praktek. Jakarta: Prestasi Pustaka Publisher.

Vanalita, M. (2014). Pengaruh model pembelajaran jigsaw terhadap kemampuan komunikasi lisan dan hasil belajar siswa. Jurnal pendidikan universitas lampung.

Vargas, M. J. (2011). Cooperative learning in virtual environments: The jigsaw method in statistical courses. Journal of international education research $7,1-8$.

Veermans, K. (2003). Intelligent support for discovery learning. Netherlands: Twente University Press.

Veermans, K. J. (2006). Use heuristics to facilitate scientific discovery learning in a simulation learning enviroment in a physics domain. International journal of science education, 28(4), 341-361.

Wenno, I. H. (2008). Strategi belajar-mengajar sains berbasis kontekstual. Yogyakarta: Inti Media.

Wulansari, A. I. (2012). Pengaruh pembelajaran kooperatif jigsaw dipadu dengan eksperimen terhadap keterampilan proses sains siswa kelas $X$ SMA Negeri 1 kartasura tahun pelajaran 2011/2012. Skripsi tidak dipublikasikan. Universitas Sebelas Maret, Surakarta. 